\title{
Wild food plants used in the villages of the Lake Vrana Nature Park (northern Dalmatia, Croatia)
}

\author{
Łukasz Łuczaj ${ }^{*}$, Norma Fressel ${ }^{2}$, Stjepan Perković ${ }^{3}$ \\ 1 Department of Botany and Biotechnology of Economic Plants, University of Rzeszów, Werynia 502, 36-100 Kolbuszowa, Poland \\ ${ }^{2}$ Nature Park Vransko Jezero, Kralja Petra Svačića 2; 23210 Biograd n/m, Croatia \\ ${ }^{3}$ Eko-Zadar, Liburnska obala 6, 23000 Zadar, Croatia
}

\section{Abstract}

Croatia is a country of diverse plant use traditions, which are still insufficiently documented. The aim of this study was to document local traditions of using wild food plants around Lake Vrana (northern Dalmatia, Zadar region).

We interviewed 43 inhabitants of six traditional villages north of Lake Vrana. On average 12 species were listed, which in total produced an inventory of 55 food plants and 3 fungi taxa. Wild vegetables were most widely collected, particularly by older women who gathered the plants mainly when herding their flocks of sheep. Wild fruits and mushrooms were rarely collected. The former used to be an important supplementary food for children, or for everyone during times of food shortage, and the latter were relatively rare due to the dry climate and shortage of woods.

The most commonly collected plants are wild vegetables: Cichorium intybus, Foeniculum vulgare, Sonchus oleraceus, Asparagus acutifolius, Papaver rhoeas, Rumex pulcher, Daucus carota, Allium ampeloprasum and Silene latifolia.

Keywords: ethnobotany, wild vegetables, wild edible plants, foraging, ethnomycology

"Šurljan baba parala / I zetu se nadala / Dođi zete do veče / Zaklat ćemo goveće / Ako dođeš popodne /Bit će ti šurljana i čorbe". A traditional rhyme recorded in the study area (Pristeg and Dobra Voda), translation below:

"An old lady picked shepherd's purse [=Capsella bursapastoris] / Hoping for her son-in-law / If you come, son by the evening / We will prepare beef / If you come in the afternoon / There will be shepherd's purse and soup".

\section{Introduction}

In some countries of Europe, e.g. Spain, Italy, Poland and Estonia, intense research on the documentation of traditionally used wild food plants has been carried out over the last few years [1-12]. In some other countries, reviews of older ethnographic literature concerning this issue have been published, e.g. Slovakia, Hungary and Sweden [13-15].

\footnotetext{
* Corresponding author. Email: lukasz.luczaj@interia.pl
} Handling Editor: Beata Zagórska-Marek

This is an Open Access digital version of the article distributed under the terms of the Creative Commons Attribution 3.0 License (creativecommons.org/licenses/by/3.0/), which permits redistribution, commercial and non-commercial, provided that the article is properly cited.
The countries of the former Yugoslavia, in spite of their great biocultural diversity have produced relatively few ethnobotanical studies concerning wild food plants. Here we should mention the articles on wild food plants used in Bosnia-Herzegovina published by the late Sulejman Redžić $[16,17]$. Also, earlier, in 1976-1979, Bakić and Popović interviewed 5000 households on the Yugoslavian coast, all the way from Istria to the present Montenegrin-Albanian border [18]. (With the exception of a small section now belonging to Bosnia-Herzegovina and Montenegro, the coast constitutes a part of Croatia). The authors asked which of the local land and aquatic plants and animals were eaten during World War II. Unfortunately only data for the most commonly used taxa are published. Bakić and Popović report the use of 120 species of vascular plants. Out of them 38 were used by more than $30 \%$ of households. Interesting observations on the plants eaten along the Adriatic coast of Croatia and sold in its local markets can also be found in the edible plant guides of Ljubiša Grlić (e.g. [19,20]). Valuable information on the wild herbs eaten on the island of Korčula is presented in a conference paper by Sardelić [21]. Scattered information on edible wild greens can also be found in Šugar's (2008) dictionary of Croatian plant names [22]. Curčićs report on the wild food plant use of Herzegovinian fishermen on the border of Dalmatia is a valuable and interesting source from as early as 1913 [23]. Last but not least, many interesting pieces of information were gathered in the recent study of wild vegetables sold in Dalmatian markets by the first author of this article and his colleagues [24].

It must be stressed that none of the above mentioned studies is a case study where a small rural area is researched 
in depth - they were either loose observations or results of larger scale questionnaires. In order to fill this gap we aimed at studying a small section of Dalmatia consisting of a few villages north of Lake Vrana, which although situated near the Adriatic, do not form part of the tourist infrastructure and consist mainly of peasant households where traditional animal husbandry and crop cultivation is maintained and constitutes the main human activity there.

\section{Material and methods}

\section{Study site}

The study site is located in northern Dalmatia and it belongs to the Zadar region, apart from the SE part, i.e. the village of Kašić, which belongs to the Šibenik-Knin region (Fig. 1-Fig. 3). We studied six villages: Vrana - 790 inhabitants, Banjevci 447, Kašić - 126, Radašinovci - 266, Pristeg - 316, and Dobra Voda - 113 (data on the number of inhabitants from the 2011 census) located in close vicinity to Lake Vrana, the largest freshwater lake in Croatia $\left(30 \mathrm{~km}^{2}\right)$ and the Vransko Jezero Nature Park $\left(57 \mathrm{~km}^{2}\right)[25,26]$. The southern border of the area was the lake and the northern border - the road No. 27 from Benkovac to Šibenik.

Nearly all the inhabitants are Roman-Catholic Croatian (95-97\% depending on the village). This stands in contrast to some villages north of the area, which are inhabited by an orthodox Serbian population and are now highly depopulated due to the tragic war in the former Yugoslavia when this area became one of the major battlefields between Croatian and Serbian military forces [27]. This resulted in severe casualties in the local population, on both sides of the conflict. For example in the village of Radašinovci it decreased from 479 in 1991 to 266 in 2011. The proportion of Roman Catholics in the village rose from $78 \%$ to $95 \%$ between 1991 and 2001 [26]. Most inhabitants make a living from mixed farming and animal husbandry (olive groves, vineyards, cereals, potatoes, sheep grazing etc.) or commute to work on the coast. The area has no tourist facilities, such as hotels or apartments, apart from a campsite near the lake. The studied villages are typical rural settlements, but the area has a rich history with several medieval ruins, including a castle. In the 11th century Vrana was an important settlement on the Dalmatian coast and the Croatian royal insignia were even held there [28].

After several pilot interviews (not included here) in settlements located in the narrow strip between the lake and coast (Drage, Pakoštane), we excluded them from this study as the level of wild plant use among the population, who make a living from tourism, is much lower there and the vegetation is slightly different, with more coastal species.

The study site is located on the edge of Ravni Kotari, a relatively flat area with gentle hills, which for centuries was one of the breadbaskets of Dalmatia. The more fertile and humid places are still cultivated or grazed but large tracts of land are abandoned and are covered by dry maquis vegetation with varying degrees of tree and shrub cover (Juniperus oxycedrus, Quercus spp.). Marshland vegetation is found around the edge of Lake Vrana.

\section{Field study}

The study was carried out mainly in the second half of March and the second half of May 2013, with preliminary observations

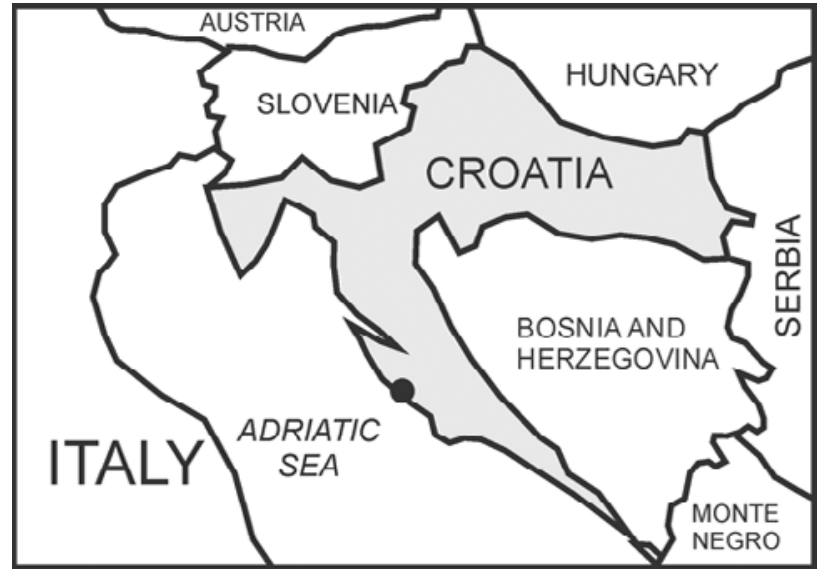

Fig. 1 Location of the study area in SE Europe.

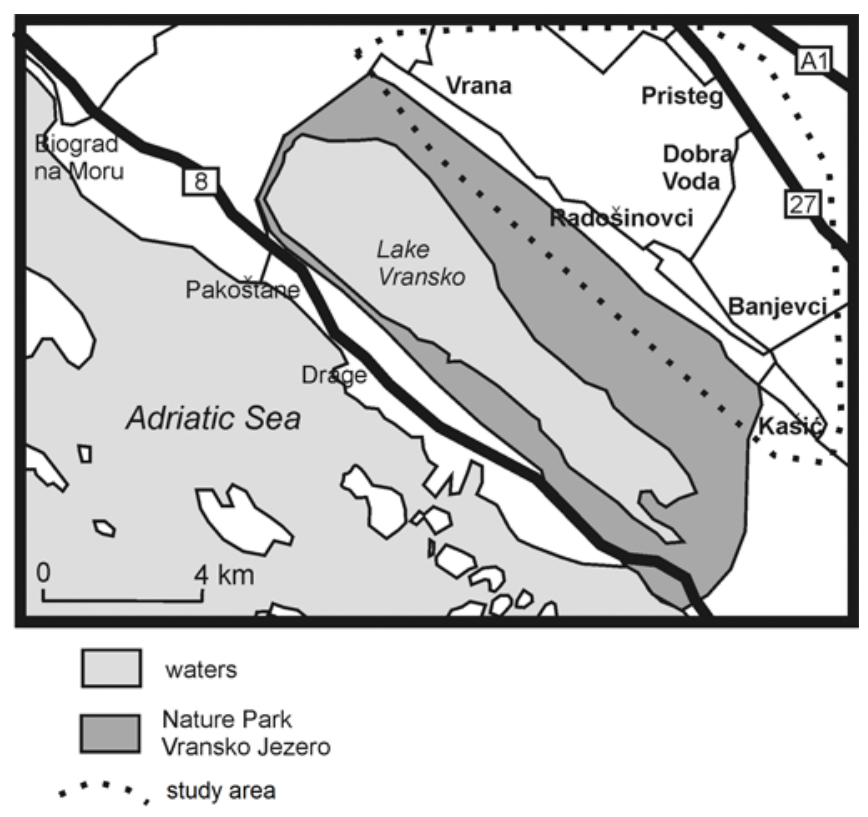

Fig. 2 The study area and the distribution of the studied villages.

carried out in spring and summer 2012. The second author is also a local nature park ranger and frequently takes part in the life of the studied villages. The research was carried out following the "American Anthropological Association code of ethics" [29] and the "International Society of Ethnobiology code of ethics" [30]. Data were collected mainly by free listing methods. Interviews were carried out in Croatian and in most cases recorded with a sound recorder, and are available from the first author.

Participants were approached outside during their farm work. Altogether, 43 free listing questionnaires were obtained, mainly from middle-aged and elderly inhabitants (33 women, aged 46 to 84 , and 10 men, aged 30 to 78 ). The mean age of informants was 62 and the median 65.

The participants were asked their age, place of origin and habitation. Then they were asked the following questions:

(i) what wild vegetables have you collected?

(ii) what wild roots have you collected?

(iii) what wild fruits have you collected?

(iv) what wild mushrooms have you collected? 


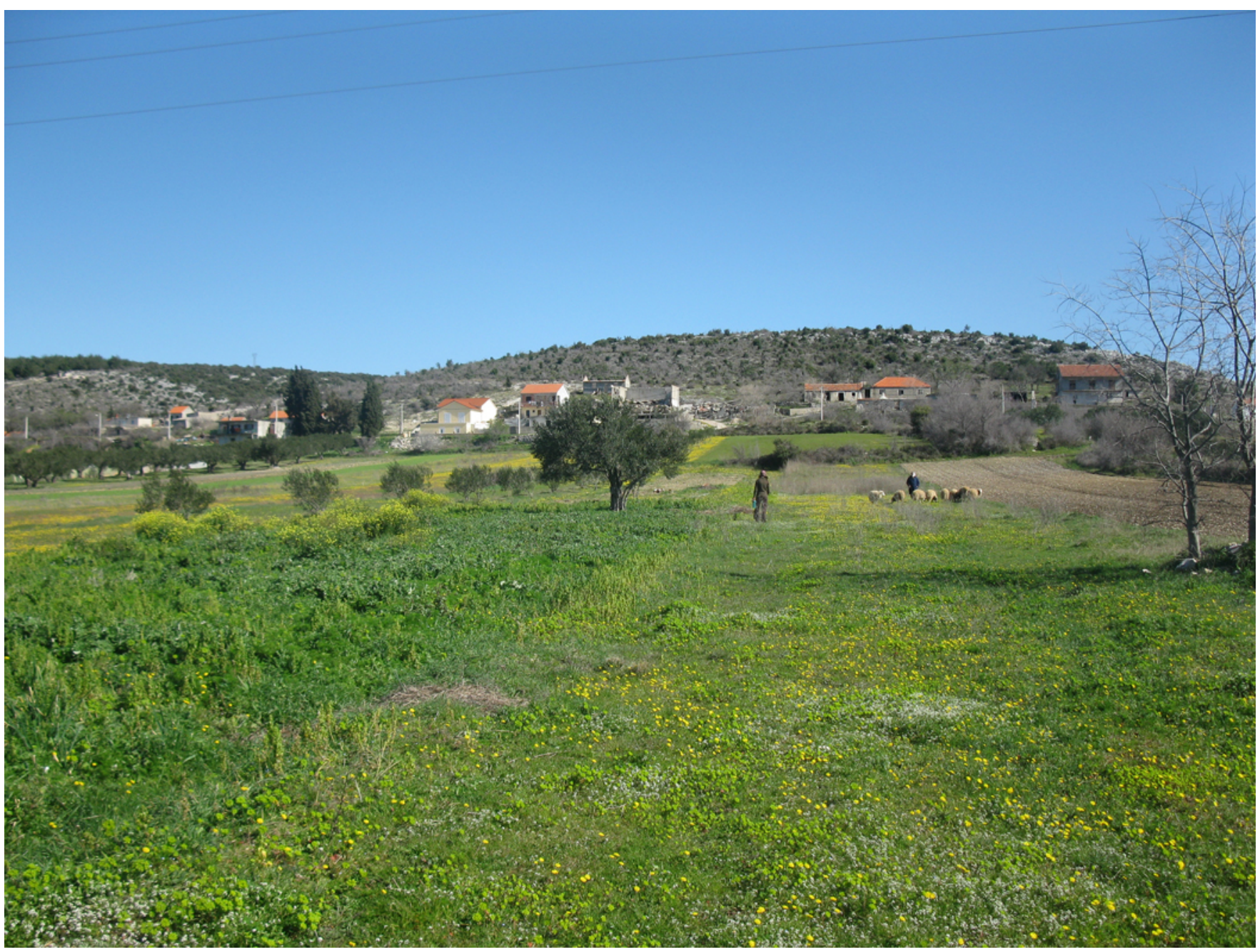

Fig. 3 A typical landscape around Vrana.

As most interviews were performed outdoors and most wild food grows in the vicinity of farms the participants usually eagerly showed the collected plants and helped us collect the voucher specimens. In the case of some rarely listed wild plants we showed them to other inhabitants in order to establish their opinion of their edibility (some plants, although rarely listed are widely known as edible in the area, e.g. Celtis australis, Lactuca serriola, Tragopogon etc.)

Voucher specimens were collected and deposited in the herbarium of the Faculty of Biology of Warsaw University (WA).

\section{Results}

Altogether, 57 species of wild food plants were recorded in the area (plus 3 taxa of mushrooms; Tab. 1, Tab. 2). This includes 37 species whose wild leaves are used, 17 species with edible fruits and 2 species whose roots are eaten. On average 12.4 species (median $=12$ ) were listed by each informant: 9.3 wild vegetables (median 9), 2.9 fruits (median 2), 0.3 roots, 0.3 fungi (median 0 for both).

Wild vegetables are still widely used in the Lake Vrana area. These are usually weeds growing in old fields, on roadsides and in hedgerows. They are mainly collected in spring (MarchApril). We often encountered shepherds who, in their spare time, filled the pockets of their aprons with wild plants, which were later brought home, sorted and used (Fig. 4, Fig. 5). Although the wild vegetables, apart from the few most common ones, like fennel or asparagus, are less popular among young people, many middle-aged people (40-50 years old) still collect them and have wide knowledge of them.

Most wild vegetables are boiled in a mix, which is called "svakober", which translates as "pick all". They are boiled for 20-30 min., strained and sprinkled with olive oil, then served as a side dish. They are often eaten with preserved ham ("pršut") or potatoes.

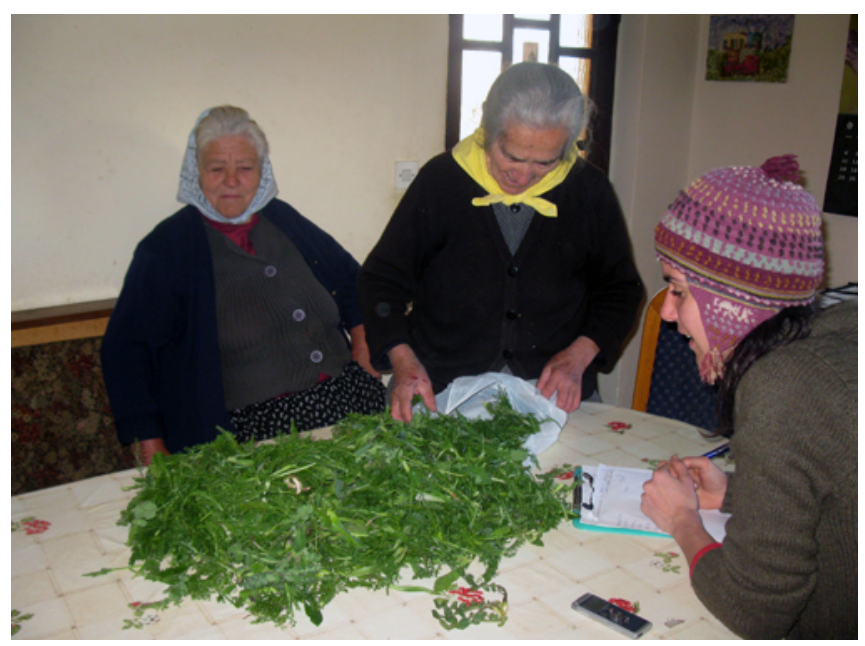

Fig. 4 Some respondents were actually encountered while coming back from trips to collect wild vegetables. 
Tab. 1 Wild food plants and mushrooms used in the area, in order of decreasing frequency.

\begin{tabular}{|c|c|c|c|c|}
\hline Folk name & Frequency $N=43$ & Species & Part & Preparation \\
\hline žutanca, žutanica, radić & 37 & Cichorium intybus L. & 1 & raw or boiled \\
\hline komorač & 33 & Foeniculum vulgare Mill. & 1 & boiled \\
\hline kostriš & 32 & Sonchus oleraceus L. & 1 & boiled \\
\hline šparoge & 29 & Asparagus acutifolius $\mathrm{L}$. & 1 & boiled, fried \\
\hline makalj, makelj, mak & 27 & Papaver rhoeas L. & 1 & boiled or raw \\
\hline štavljak & 26 & Rumex pulcher $\mathrm{L}$. & 1 & boiled \\
\hline divlja mrkva, mrkvica & 25 & Daucus carota $\mathrm{L}$. & $1, \mathrm{r}$ & boiled (leaves), raw (roots) \\
\hline divlji luk & 23 & Allium ampeloprasum L. & 1 & raw or boiled \\
\hline ušac & 23 & Silene latifolia Poir. & 1 & boiled \\
\hline $\begin{array}{l}\text { brmbeč, brmečica, brmečuša, } \\
\text { sikavac }\end{array}$ & 20 & $\begin{array}{l}\text { Scolymus hispanicus L. and Eryngium } \\
\text { campestre L. }\end{array}$ & $1, \mathrm{r}$ & boiled \\
\hline kopriva & 18 & Urtica dioica $\mathrm{L}$ & 1 & boiled, dried for medicine \\
\hline divlja jagoda, kupina & 17 & Rubus ulmifolius Schott & $\mathrm{f}$ & tea, raw, jam \\
\hline prva, planika, maginja, magunja & 15 & Arbutus unedo L. & $\mathrm{f}$ & rakija, pekmez, raw \\
\hline divlja kruška, divlje jabuka & 12 & Pyrus amygdaliformis Vill. & $\mathrm{f}$ & raw \\
\hline drinina, drinjina, dren & 11 & Cornus mas L. & $\mathrm{f}$ & raw \\
\hline kozija brada & 11 & $\begin{array}{c}\text { Scorzonera laciniata L., Tragopogon } \\
\text { pratensis L. and related taxa }\end{array}$ & 1 & boiled \\
\hline krastavac, širopica, & 10 & Picris echioides L. & 1 & boiled \\
\hline dimovac & 9 & Crepis sancta (L.) Babc. & 1 & boiled \\
\hline smreka, smrika, kozarača & 9 & $\begin{array}{l}\text { Juniperus macrocarpa Sibth. and Sm., } \\
\text { Juniperus oxycedrus L. }\end{array}$ & $\mathrm{f}$ & raw and in rakija \\
\hline trnina & 9 & Prunus spinosa L. & $\mathrm{f}$ & raw \\
\hline pečurke & 7 & Agaricus sp. & $\mathrm{m}$ & boiled \\
\hline iglica & 6 & Erodium cicutarium (L.) L’Her. ex Aiton & 1 & boiled \\
\hline salatuša, divlja salata & 6 & Lactuca serriola $\mathrm{L}$ & 1 & raw and cooked \\
\hline kravlja gubica & 6 & $\begin{array}{l}\text { an unidentified name of an Asteraceae } \\
\text { plant }\end{array}$ & 1 & boiled \\
\hline šurljen, šurljan & 5 & Capsella bursa-pastoris $\mathrm{L}$. & 1 & boiled, also in soup \\
\hline tavka & 5 & Chondrilla juncea L. & 1 & raw salad \\
\hline gloginje, glog & 5 & Crataegus monogyna Jacq. & $\mathrm{f}$ & raw \\
\hline žir [name of acorns] & 5 & Quercus ilex L. and Q. pubescens Willd. & $\mathrm{f}$ & baked and boiled, until World War II \\
\hline oskoruša & 5 & Sorbus domestica L. & $\mathrm{f}$ & raw and dried \\
\hline kokna volica, koknja volica & 5 & Viola arvensis Murray & 1 & boiled \\
\hline štir & 4 & Amaranthus retroflexus L. & 1 & boiled \\
\hline koštela & 4 & Celtis australis L. & $\mathrm{f}$ & raw, also rakija \\
\hline drača, kolačći, kolači & 4 & Paliurus spina-christi Mill. & $\mathrm{f}$ & immature fruits eaten as a children's snack \\
\hline škripac, škripavac, ušac & 4 & $\begin{array}{c}\text { Silene vulgaris (Mch.) Garcke ssp. } \\
\text { angustifolia Hayek }\end{array}$ & 1 & boiled \\
\hline svičica & 4 & Torilis nodosa (L.) Gaertn. & 1 & boiled \\
\hline loboda, laboda & 3 & Chenopodium album L. & 1 & boiled \\
\hline crvenjak, crvenki & 3 & Geranium molle L. & 1 & boiled \\
\hline šliz, sliz, sljez & 3 & Malva sylvestris $\mathrm{L}$. & 1 & boiled \\
\hline divlja maslina & 3 & Olea europaea L. & $\mathrm{f}$ & pressed into oil \\
\hline bljušt, kukljar,kukelj, kukač & 3 & Tamus communis L. & 1 & boiled \\
\hline \multirow[t]{2}{*}{ divlja blitva } & 2 & Beta vulgaris subsp. maritima (L.) & 1 & boiled \\
\hline & & Moq. (syn. B. maritima L.) & & \\
\hline sikovac & 2 & Cirsium sp. & 1 & boiled \\
\hline čelica, kubljanac & 2 & Lamium amplexicaule $\mathrm{L}$. & 1 & boiled \\
\hline sunčenica, sunčanica & 2 & Macrolepiota cf procera (Scop.) Singer & $\mathrm{m}$ & fried, boiled \\
\hline murva divlja & 2 & Morus nigra $\mathrm{L}$. & $\mathrm{f}$ & raw \\
\hline kupusak, kupusić & 2 & Myagrum perfoliatum L. & 1 & boiled \\
\hline gorušica, ognica & 2 & Sinapis arvensis L. & 1 & boiled \\
\hline vunica, mišakinja & 2 & Stellaria media L. & 1 & boiled \\
\hline maslačak & 2 & Taraxacum sp. pl. & 1 & raw or boiled \\
\hline vrganj & 1 & Boletus section Edulae & $\mathrm{m}$ & \\
\hline rogač & 1 & Ceratonia siliqua L. & $\mathrm{f}$ & \\
\hline slačak & 1 & Convolvulus arvensis L. & 1 & boiled \\
\hline trputac & 1 & Plantago cf major L. & 1 & boiled \\
\hline
\end{tabular}


Tab. 1 (continued)

\begin{tabular}{lcccc} 
& Folk name & Frequency $\mathbf{N = 4 3}$ & Ppecies & Preparation \\
\hline štucanj & 1 & Portulacca oleracea L. & 1 & boiled \\
rašeljka & 1 & Prunus mahaleb L. & $\mathrm{f}$ & f \\
brekinja & 1 & Sorbus torminalis (L.) Crantz & $\mathrm{f}$ & boiled \\
ditelnica & 1 & Trifolium sp. & 1 & \\
\hline
\end{tabular}

Part used: $\mathrm{f}$ - fruits; $\mathrm{h}$ - aerial parts as aromatic spice; 1 - young leaves or young rosettes, used for boiled salads; $\mathrm{m}$ - mushrooms.

Tab. 2 Plants mainly used as medicine, but mentioned in our questionnaire as a source of everyday infusions ("recreational" tea).

\begin{tabular}{|c|c|c|c|c|}
\hline Folk name & Frequency $N=43$ & Species & Part & Preparation \\
\hline šipak & 14 & Rosa canina L. & $\mathrm{f}$ & infusion \\
\hline kadulja & 10 & Salvia officinalis L. & 1 & infusion, rakija \\
\hline stolisnik & 2 & Achillea cf millefolium L. & $1, \mathrm{fl}$ & infusion \\
\hline smilje & 2 & Helichrysum italicum (Roth) G. Don & $\mathrm{fl}, 1$ & infusion, rakija \\
\hline metvica divlja, menta & 2 & Mentha spp. & 1 & infusion \\
\hline buhač & 1 & Anthemis sp. & $\mathrm{fl}$ & infusion \\
\hline pelin & 1 & Artemisia absinthium L. & 1 & infusion \\
\hline matičnjak & 1 & Melissa officinalis L. & 1 & infusion \\
\hline gospina trava & 1 & Hypericum perforatum $\mathrm{L}$. & $\mathrm{fl}$ & infusion \\
\hline rutva & 1 & Ruta graveolens L. & 1 & infusion \\
\hline majčina dušica & 1 & Thymus sp. & $\mathrm{fl}, 1$ & infusion \\
\hline lipa & 1 & $\begin{array}{c}\text { Tilia cordata Mill., T. tomentosa Moench, } \\
\text { T. platyphyllos Scop. }\end{array}$ & $\mathrm{fl}$ & infusion \\
\hline
\end{tabular}

Part used: $\mathrm{f}$ - fruit; $\mathrm{fl}$ - flowers; 1 - leafy parts.

Asparagus shoots are boiled separately and served in the same way. Some Asteraceae species are also eaten raw or blanched, and dressed in olive oil (Cichorium, Taraxacum etc.).

Fennel (Foeniculum vulgare) is used both as a vegetable and a spice, added to svakober, and other dishes. It is often added to boiled broad beans (Vicia faba), which is one of the traditional local specialities.

Wild fruits are now rarely collected, apart from snacking on blackberries or collecting Rosa fruits for tea. In the past (up until the 1960s) they were widely collected by undernourished children, and made into jams ("pekmez") or added to homemade fruit brandy ("rakija"). Now this is only occasionally done.

Wild mushrooms are little known and little collected. There is only one forest in the area (a few dozen ha of oak wood) and some people, rarely, collect Boletus there. The only two more frequently collected mushroom taxa are Agaricus and Macrolepiota procera, both gathered from open pastures.

\section{Discussion}

The presented list of wild foods is also typical for other Mediterranean areas. Most of the wild vegetables and fruits collected in the Vrana area are also widely used in Spain and Italy. This confirms our hypothesis that as far as the collection of wild food is concerned, the area forms part of a Mediterranean cultural

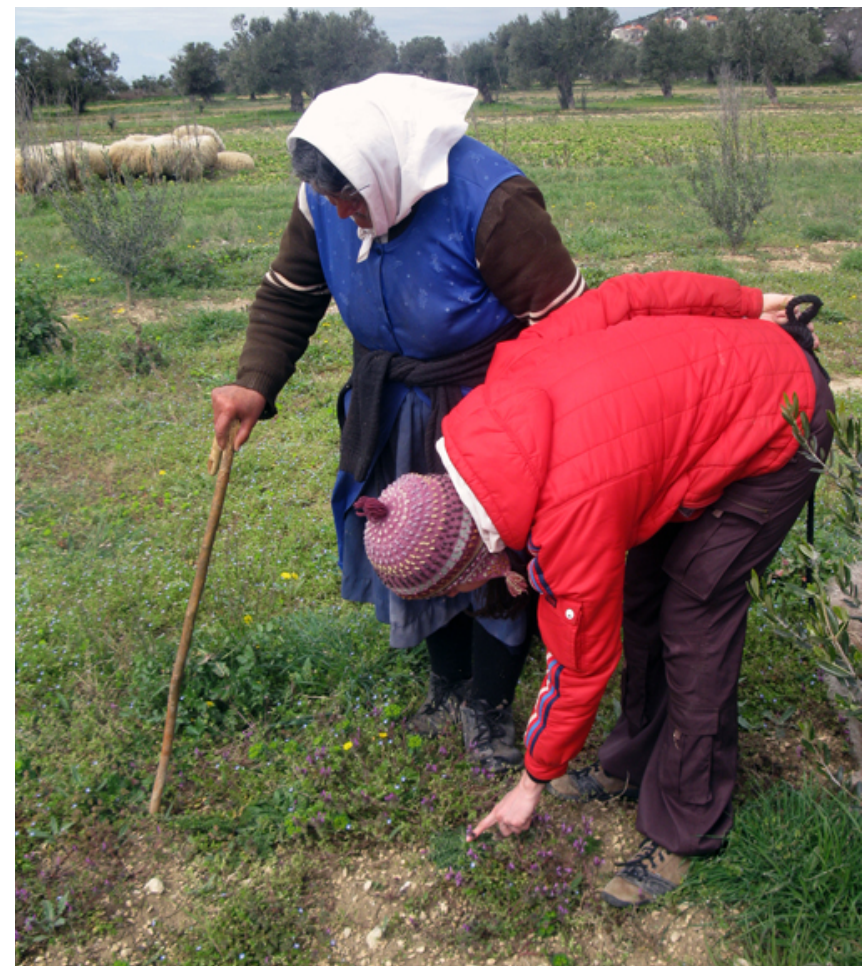

Fig. 5 Collecting wild vegetables is often an additional activity when looking after herds of sheep - the plants are put in the pockets of an apron. 
area, spreading from Spain to western Turkey $[1-5,31,32]$. On the other hand worthy of attention is the use of Myagrum perfoliatum (Brassicaceae) and Torilis nodosa (Apiaceae), species whose consumption had not been previously reported by any ethnobotanical studies. Only a related species from the genus Torilis, i.e. Torilis arvensis (Huds.) Link subsp. arvensis, is used as a spice in Crete [32]. The list of recorded wild greens is long on a European scale, but shorter than the number of wild greens used in some parts of Asia (e.g. $[33,34])$.

The frequency of quoting wild vegetable use in this study is similar to the frequency of wild vegetables sold in the whole of Dalmatia as recorded in research in local markets [24] and as recorded by Bakić and Popović over 30 years ago (Tab. 3) [18]. For more than half of the more common taxa there were no significant differences in frequency. Only Rumex pulcher is a special case, very rarely sold in the markets but commonly eaten in the area. This similarity of data from the markets and from local study confirms the great usefulness of market surveys. Market surveys allow for quick and easy data gathering and they also enable confirmation of which species are actually used on a larger scale [35-38]. The two main disadvantages of market surveys are the danger of recording plants sold for outsiders, e.g. town inhabitants or tourists, which may be very different from the plants eaten in the countryside, and the omission of plants, which may not be sold but are used. In the case of Dalmatia, however, we see a large similarity in the locally eaten mix and the mixes sold in the Dalmatian markets.

Tab. 3 Comparison of frequency of wild vegetables used in salad mixes (not separately, like Asparagus, Tamus and Cichorium) in questionnaires from the Vrana area and from market surveys in the whole of Dalmatia [24].

\begin{tabular}{cccc}
\hline & $\begin{array}{c}\text { Markets } \\
\mathbf{N =} \mathbf{6 8}(\%)\end{array}$ & $\begin{array}{c}\text { Vrana area } \\
\mathbf{N = 4 3}(\%)\end{array}$ & $\begin{array}{c}\text { Significance } \\
\text { chi-squared test }\end{array}$ \\
Species & & & \\
Foeniculum vulgare & 63 & 86 & \\
Lactuca serriola & 7 & 14 & \\
Picris echioides & 40 & 23 & \\
Sonchus olearaceus & 79 & 74 & \\
Taraxacum spp. & 15 & 4 & $* * *$ \\
Silene latifolia & 13 & 53 & $*$ \\
Papaver rhoeas & 41 & 63 & $*$ \\
Tragopogon \& Scrozonera & 9 & 26 & $*$ \\
Daucus carota & 19 & 58 & $*$ \\
Rumex pulcher & 3 & 60 & \\
Allium ampeloprasum & 69 & 53 & \\
\hline
\end{tabular}

Significance: ${ }^{\star} P<0.05 ;{ }^{*} P<0.01 ;{ }^{* *} P<0.001$.

Out of the 36 wild food plant taxa listed by Bakić and Popović [18] as the most frequently used on the ex-Yugoslav coast, as many as 29 species (or their close relatives from the same genus) are used or remembered in the Vrana area.

As the study area is located several kilometres from the coast, no typical seashore edibles, like Salicornia salina and Plantago coronopus, eaten in some parts of Dalmatia, were recorded in this study.

The accidentally recorded plants used for everyday infusions in the Vrana area are species widely used around the
Mediterranean or in other Slavic countries (e.g. [39]). This is probably only a small proportion of the medicinal plants known in the area. The erosion of local plant knowledge in the Vrana area seems to be much smaller than on other parts of the Croatian coast, for instance on the more developed Istria [40] or around Dubrovnik (personal observations).

This study clearly confirms that this part of Dalmatia is clearly one the very few parts of herbophilous Slavic territories where the use of wild greens is still common. In northern Slavic countries [6-10,14,41,42] as well as northern Croatia (authors' personal observations) wild greens are either no longer used at all, or only one or a few species are known and utilized, although up to the 19th century, their use had been more widespread [43]. On the other hand, in the predominantly woodless Dalmatia, mushrooms are little utilized compared to central and northern Croatia and other Slavic countries (e.g. [44]). Research is needed in other parts of Croatia and neighbouring countries to broaden our knowledge of plant use patterns.

\section{Acknowledgments}

The research was financially supported by the University of Rzeszów (Institute of Applied Biotechnology and Basic Sciences, as well as a special grant from the vice-rector of the university Prof. S. Czopek). Many thanks to Dr. Marija Pandža for identifying a few herbarium specimens.

\section{Authors' contributions}

The following declarations about authors' contributions to the research have been made: carried out the interviews: $Ł €$, NF, SP; wrote the manuscript: $Ł €$.

\section{References}

1. Pieroni A. Evaluation of the cultural significance of wild food botanicals traditionally consumed in Northwestern Tuscany, Italy. J Ethnobiol. 2001;21(1):89-104.

2. Ghirardini MP, Carli M, del Vecchio N, Rovati A, Cova O, Valigi F, et al. The importance of a taste. A comparative study on wild food plant consumption in twenty-one local communities in Italy. J Ethnobiol Ethnomed. 2007;3(1):22. http://dx.doi.org/10.1186/1746-4269-3-22

3. Tardío J, Pardo-De-Santayana M, Morales R. Ethnobotanical review of wild edible plants in Spain. Bot J Linn Soc. 2006;152(1):27-71. http:// dx.doi.org/10.1111/j.1095-8339.2006.00549.x

4. Bonet MÀ, Vallès J. Use of non-crop food vascular plants in Montseny biosphere reserve (Catalonia, Iberian Peninsula). Int J Food Sci Nutr. 2002;53(3):225-248. http://dx.doi.org/10.1080/09637480220132841

5. Leonti M, Nebel S, Rivera D, Heinrich M. Wild gathered food plants in the European Mediterranean: a comparative analysis. Econ Bot. 2006;60(2):130-142. http://dx.doi.org/10.1663/0013-0001(2006)60[130:WG FPIT]2.0.CO;2

6. Łuczaj Ł, Pieroni A, Tardío J, Pardo-de-Santayana M, Sõukand R, Svanberg I, et al. Wild food plant use in 21 st century Europe: the disappearance of old traditions and the search for new cuisines involving wild edibles. Acta Soc Bot Pol. 2012;81(4):359-370. http://dx.doi.org/10.5586/asbp.2012.031

7. Łuczaj Ł. Archival data on wild food plants used in Poland in 1948. J Ethnobiol Ethnomed. 2008;4(1):4. http://dx.doi.org/10.1186/1746-4269-4-4

8. Łuczaj $Ł$. Changes in the utilization of wild green vegetables in Poland since the 19th century: a comparison of four ethnobotanical surveys. 
J Ethnopharmacol. 2010;128(2):395-404. http://dx.doi.org/10.1016/j. jep.2010.01.038

9. Łuczaj $€$, Szymański WM. Wild vascular plants gathered for consumption in the Polish countryside: a review. J Ethnobiol Ethnomed. 2007;3(1):17. http://dx.doi.org/10.1186/1746-4269-3-17

10. Łuczaj Ł. Dziko rosnące rośliny jadalne użytkowane w Polsce od połowy XIX w. do czasów współczesnych. Etnobiologia Pol. 2011;1:57-125.

11. Kalle R, Sõukand R. Historical ethnobotanical review of wild edible plants of Estonia (1770s-1960s). Acta Soc Bot Pol. 2012;81(4):271-281. http:// dx.doi.org/10.5586/asbp.2012.033

12. Kalle R, Sõukand R. Wild plants eaten in childhood: a retrospective of Estonia in the 1970s-1990s: Wild plants eaten in childhood in Estonia. Bot J Linn Soc. 2013;172(2):239-253. http://dx.doi.org/10.1111/boj.12051

13. Dénes A, Papp N, Babai D, Czúcz B, Molnár Z. Wild plants used for food by Hungarian ethnic groups living in the Carpathian Basin. Acta Soc Bot Pol. 2012;81(4):381-396. http://dx.doi.org/10.5586/asbp.2012.040

14. Łuczaj $Ł$. Ethnobotanical review of wild edible plants of Slovakia. Acta Soc Bot Pol. 2012;81(4):245-255. http://dx.doi.org/10.5586/asbp.2012.030

15. Svanberg I. The use of wild plants as food in pre-industrial Sweden. Acta Soc Bot Pol. 2012;81(4):317-327. http://dx.doi.org/10.5586/asbp.2012.039

16. Jman Redzic $S$. Wild edible plants and their traditional use in the human nutrition in Bosnia-Herzegovina. Ecol Food Nutr. 2006;45(3):189-232. http://dx.doi.org/10.1080/03670240600648963

17. Redzić $S$. Use of wild and semi-wild edible plants in nutrition and survival of people in 1430 days of siege of Sarajevo during the war in Bosnia and Herzegovina (1992-1995). Coll Antropol. 2010;34(2):551-570.

18. Bakić J, Popović M. Nekonvencionalni izvori u ishrani na otocima i priobalju u toku NOR-a. Beograd. Beograd: Izd. Mornaričkog glasnika; 1983.

19. Grlić L. Enciklopedija samoniklog jestivog bilja. Rijeka: Ex Libris; 2005.

20. Grlić L. Enciklopedija samoniklog jestivog bilja. Zagreb: August Cesarec; 1986.

21. Sardelić S. Samoniklo jestivo bilje - mišanca, gruda, parapač... wild edible herbs - Mišanca, Gruda, Parapač. Etnološka Istraživanja. 2008;1(12-13):387-396.

22. Šugar I. Hrvatski biljni imenoslov. Nomenclator botanicus Croaticus. Zagreb: Matica Hrvatska; 2008.

23. Ćurčić V. Narodno ribarstvo u Bosni i Hercegovini. Part 2. Glas. Zemalj. Muzeja U Bosni Hercegovini. 1913;25:464-465.

24. Łuczaj $€$, Zovko Končić M, Miličević T, Dolina K, Pandža M. Wild vegetable mixes sold in the markets of Dalmatia (southern Croatia). J Ethnobiol Ethnomed. 2013;9(1):2. http://dx.doi.org/10.1186/1746-4269-9-2

25. Park prirode Vranske Jezero [Internet]. 2013 [cited 2013 Sep 10]; Available from: http://www.vransko-jezero.hr

26. Naselja i stanovništvo Republike Hrvatske [Internet]. 2013 [cited 2013 Nov 26]; Available from: http://www.dzs.hr/Hrv/pxweb2003/database/ Naselja\%20i\%20stanovnistvo\%20Republike\%20Hrvatske/Naselja\%20 i\%20stanovnistvo\%20Republike\%20Hrvatske.asp

27. Thomas N, Mikulan K. Slovenia \& Croatia 1991-95. Oxford: Osprey Publishing; 2006.

28. Jackson TG. Dalmatia. Oxford: Clarendon Press; 1887.
29. American Anthropological Association code of ethics [Internet]. [cited 2013 Sep 10]; Available from: http://www.aaanet.org/issues/policyadvocacy/upload/AAA-Ethics-Code-2009.pdf

30. International Society of Ethnobiology code of ethics (with 2008 additions) [Internet]. [cited 2013 Sep 10]; Available from: http://ethnobiology.net/ code-of-ethics/

31. Dogan Y. Traditionally used wild edible greens in the Aegean Region of Turkey. Acta Soc Bot Pol. 2012;81(4):329-342. http://dx.doi.org/10.5586/ asbp. 2012.037

32. Hadjichambis AC, Paraskeva-Hadjichambi D, Della A, Giusti ME, De Pasquale C, Lenzarini C, et al. Wild and semi-domesticated food plant consumption in seven circum-Mediterranean areas. Int J Food Sci Nutr. 2008;59(5):383-414.

33. Kang Y, Łuczaj $€$, Ye S, Zhang S, Kang J. Wild food plants and wild edible fungi of Heihe valley (Qinling Mountains, Shaanxi, central China): herbophilia and indifference to fruits and mushrooms. Acta Soc Bot Pol. 2012;81(4):405-413. http://dx.doi.org/10.5586/asbp.2012.044

34. Kang Y, Łuczaj $€$, Kang J, Zhang S. Wild food plants and wild edible fungi in two valleys of the Qinling Mountains (Shaanxi, central China). J Ethnobiol Ethnomed. 2013;9(1):26. http://dx.doi.org/10.1186/1746-4269-9-26

35. Nguyen MLT, Doherty KT, Wieting J. Market survey research: a model for ethnobotanical education. Ethnobot Res Appl. 2008;6:87-92.

36. Bye RA, Linares E. The role of plants found in the Mexican markets and their importance in ethnobotanical studies. J Ethnobiol. 1983;3:1-13.

37. Pemberton RW, Lee NS. Wild food plants in South Korea; market presence, new crops, and exports to the United States. Econ Bot. 1996;50(1):57-70. http://dx.doi.org/10.1007/BF02862113

38. You-kai X, Guo-Da T, Hong-Mao L, Kang-La Y, Xiang-Sheng D. Wild vegetable resources and market survey in Xishuangbanna, Southwest China. Econ Bot. 2004;58(4):647-667. http://dx.doi. org/10.1663/0013-0001(2004)058[0647:WVRAMS]2.0.CO;2

39. Sõukand R, Quave CL, Pieroni A, Pardo-de-Santayana M, Tardío J, Kalle R, et al. Plants used for making recreational tea in Europe: a review based on specific research sites. J Ethnobiol Ethnomed. 2013;9(1):58. http://dx.doi. org/10.1186/1746-4269-9-58

40. Pieroni A, Giusti ME. The remedies of the folk medicine of the Croatians living in Cićarija, northern Istria. Coll Antropol. 2008;32(2):623-627.

41. Łuczaj $€ J$. Plant identification credibility in ethnobotany: a closer look at Polish ethnographic studies. J Ethnobiol Ethnomed. 2010;6(1):36. http:// dx.doi.org/10.1186/1746-4269-6-36

42. Łuczaj ŁJ, Kujawska M. Botanists and their childhood memories: an under-utilized expert source in ethnobotanical research. Bot J Linn Soc. 2012;168(3):334-343. http://dx.doi.org/10.1111/j.1095-8339.2011.01205.x

43. Łuczaj Ł, Köhler P, Pirożnikow E, Graniszewska M, Pieroni A, Gervasi T. Wild edible plants of Belarus: from Rostafiński's questionnaire of 1883 to the present. J Ethnobiol Ethnomed. 2013;9(1):21. http://dx.doi. org/10.1186/1746-4269-9-21

44. Łuczaj $Ł$, Nieroda Z. Collecting and learning to identify edible fungi in Southeastern Poland: age and gender differences. Ecol Food Nutr. 2011;50(4):319-336. http://dx.doi.org/10.1080/03670244.2011.586314 